TECHNICAL NOTE

\title{
ADVANCES IN EARTHQUAKE ENGINEERING
}

\section{A.J. O'Leary*}

\section{INTRODUCTION}

The writer attended a short course entitled "Advances in Earthquake Engineering"from 16 to 20 June 1980 at the University of Californis, Berkeley. course was organised by "Continuing Education in Engineering, University Extension, and the College of Engineering" UC Berkeley. The course is run every few years, and as the title implies is an attempt to bring together in the form of a series of lectures all recent developments in the fields of engineering seismology, seismic resistant design of civil and building structures, and seismic analysis. Approximately 250 attended this course, the majority being from the USA and in particular California, but with several participants from Canada, Central and South America, a few from Japan, Europe, Australia and two from New Zealand.

\section{COURSE CONTENT}

The course content could be broadly divided into five sections, namely:

\section{Earthquake sources, measurement} and characteristics.

2. Seismic properties of soils and earth structures, including soilstructure interaction.

3. Concrete dams.

4. Structures including masonry, offshore structures, bridges, tanks, and structural performance of components.

5. Risk analysis.

\section{PAPERS PRESENTED}

M.G. Bonilla opened the course with a lecture on surface faulting and its relation to earthquake engineering. He described aspects of surface faulting that are of concern in planning and design. He made brief remarks on estimates of future displacements concluding with the observation that these are difficult to estimate and are imprecise and that prediction of sizes of future earthquakes at particular sites should only be made by comparing several methods. Future faulting will generally occur along existing faults as new faulting is unusual.

D.I. Gough discussed the state of knowledge of earthquakes induced by the construction of large reservoirs, and the

*Associate, Morrison Cooper \& Partners, Wellington, New Zealand injection of fluid into crustal rocks. Both fractures and near-critical stresses of tectonic origin are necessary to induce earthquakes and the reservoir triggers failure, occasionally by increment to the tectonic stresses but more usually by increase of fluid pressure. The effect of increase of fluid pressure may be delayed for a year or more.

D.E. Hudson's lecture was based on types and characteristics of various earthquake motion recorders. His and B.A. Bolt's material on instrument arrays was directed more at engineering seismologists than design engineers.

These were followed by a lecture entitled "The Design Earthquake" given by $G$. Housner. He produced a large amount of information on past events including some useful correlations between magnitude and fault length, peak acceleration and distance from fault for various magnitudes and duration of strong shaking and magnitude. Much of his information was California related but his general comments and correlations are applicable to other seismic areas of the world. However, in conclusion, he sounded a caution to those who expect precise information on future events. He observed that even two events at the same site can and generally do have only very broad similarities.

The next several sessions covered seismic engineering as related to soils, earth structures, and soil-structure interaction. These lectures were given by K.H. Stokoe on measurement of dynamic properties of soils, particularly compression and shear wave velocities from which much data can be obtained on soil response. see also references 1,2 and 3 .

H.B. Seed and J. Lysmer gave a two part lecture on soil-structure interaction. 4 The soil-structure interaction problem is the determination of the motions of one or more structures at a given site from a knowledge of a given motion at a specified point of the site prior to construction. A complete soil-structure interaction analysis for any structure must necessarily consist of two distinct parts; a site response analysis and an interaction analysis.

Professor seed then presented a very interesting lecture on earth dam design in which he discussed several failures, causes of failure and defensive design. 5 This was followed by an extensive overview of in-place improvement of unstable soils by J.K. Mitchell.

Two lectures on seismic performance of masonry structures and panels were given by R.L. Mayes and H.D. MicNiven.

Part of Doctor Mayes' presentation included information on a research project 
on single storey masonry houses with minimum seismic reinforcement requirements for areas of low seismic activity in the U.S.A. viz U.B.C. seismic Zone 2 areas. The information and conclusions from this part of the presentation were not regarded as relevant to New Zealand conditions.

The remainder of Dr Mayes' lecture and all that of professor MCNiven's concerned an experimental study of multi-storey masonry buildings. Detailed test procedures and the results of cyclic loading on single and double pier test specimens were reported. Briefly the results of the tests related to the requirements of $\mathrm{ATC}-3-06^{6}$ were:

(i) Where masonry takes all the shear the ATC-3-06 requirements are on the non-conservative side for walls with an $\mathrm{M} / \mathrm{Vd}$ ratio of 1 , where $\mathrm{M}=$ Moment, $\mathrm{V}=$ Shear, and d = effective depth.

(ii) For heavily reinforced walls where the reinforcement takes all the shear, ATC-3-06 is clearly non-conservative for walls with an $\mathrm{M} / \mathrm{Vd}$ ratio of 1 and is also non-conservative for walls with an M/Vd ratio of 0 . The allowable stresses are too high in both instances.

(iii) Some changes in ATC-3-06 provisions are warranted.

The tests reported are part of a continuing series of tests on masonry structures and for those interested it is suggested that the EERC University of California, Berkeley, be contacted for the latest research reports.

A.K. Chopra discussed aspects of dynamic response, hydrodynamic effects and earthquake ground motion properties of concrete gravity dams 7,8 . Preliminary and detailed total design procedures were presented. Still on the subject of dams R.W. Clough presented a mathematical model for the analysis of response of arch dams and R.L. Weigel discussed tsunamis and landslide generated waves in reservoirs.

Professor Clough closed the third day with a report on dynamic testing of thin wall tanks 9 . Important findings were that out-of-round distortions produce stresses and deflections that are not negligible, and that uplift behaviour of unanchored tanks differ greatly from that traditionally assumed in design with observed stresses several times larger than expected.

The fourth day opened with a lecture by $\mathrm{J}$. Penzien on three dimensional dynamic analysis of fixed offshore platforms 10. Then B.J. Watt described practical analysis techniques and design philosophy as applicable to both steel and concrete offshore structures. Guidance in design of these structures can be found in API RP2All and ACl $357^{12}$ respectively. He was one of the very few lecturers who discussed capacity design techniques.

Because of the Iimited time watt was unable to expand on capacity design of structures as related to steel platforms but commented that "The emphasis of the whole design is to control the failure modes of the system and to ensure good post yield behaviour in the event of an extreme earthquake".

Two presentations on analysis and design of bridges followed. Professor Penzien and R.A. Imbsen gave details of current work being undertaken including both computer and hand analysis techniques for response of bridges. Much of the work reported is to be incorporated in proposed new code provisions for bridge design, viz. the Applied Technology Council Report No. 6. A single mode spectral approach for short bridges, appropriate for hand analysis, was discussed in detail.

Risk analysis was the subject of the final paper on the fourth dayl3. Three objectives were given:

(i) Probabilistic assessment of future ground motion:

(ii) seismic reliability assessment of structural systems;

and

(iii) risk of lifeline.

A model for risk analysis was developed and its use for a site in San Francisco was illustrated.

H.J. Degenkolb opened the final day with an interesting and very enlightening discussion on learning from earthquakes. He was able to bring a long practical career in earthquake resistant engineering to bear on observations in the ultimate testing laboratory, the sites of large earthquakes. He pointed out how many in the profession do not seem to learn from unfortunate experiences of others and how codes lag many years behind knowledge gained both in the field and in the laboratory.

Presentations by V.V. Bertero on detailed study of building damage, and E.P. Popov on seismic behaviour of structural sub-assemblages continued what was in the view of many the most rewarding series of lectures of the-whole course. Both highlighted what many consider the real design problem: It is not so much how the problem is analysed but rather how the structure is detailed.

Professor Bertero's lecture can best be summarised by quoting the "conclusions" from his paper. "The above lessons and findings (from study of building performance) clearly indicate that at present, because of large uncertainties in estimating the demands of the earthquake resistant design of buildings, it is of paramount importance to pay more attention to "conceptual" than to "numerical" 
design. Sophistication in selection of building layout (structural system, structural material, nonstructural components) is at present more important than sophistication in estimating demands (analysis). Proper construction and maintenance of the building are crucial. A design can only be effective if it can be constructed and maintained. Thorough inspection during and after construction is a must in seismic-resistant construction."

Professor Popov discussed hysteretic behaviour of several sub-assemblages 14 including steel material ductility, member ductility and sub-assemblage ductility. He spent some time reporting recent findings on eccentrically braced steel frames. Reinforced concrete material, member and sub-assemblages ductility followed.

The two concluding papers were on reconciliation of ground motion and response by J.A. Blume and a survey of isolation systems by J.M. Kelly.

NEW ZEALAND PRACTICE COMPARED TO THAT IN THE U.S.A.

Broadly New Zealand seismic engineering practice is in line with that of California. Because of the higher level of earthquake activity on the western seaboard compared to the rest of the country, Californian practice leads that of the rest of the United States. Thus a large majority of all seismic understanding emanates from the Universities and practising engineers located within California and for this reason it is appropriate to compare our own practice with that of California.

Similar difficulties seem to be experienced in both countries in getting the most up to date knowledge into building and other codes of practice and standards. It was stated by one lecturer during his presentation that codes lag behing current state of the art by up to ten years. The time may or may not be shorter in New Zealand but the time gap between good modern practice and codified requirements as reflected in administration of by-laws is certainly longer than many consider desirable. For this reason engineers in both countries are sometimes designing to far higher standards than those officially accepted as adequate simply because they are keeping up with the most recent developments in their field rather than waiting for the requirements to become mandatory through codes.

Designers in California have access to quite sophisticated analysis techniques for a large number of problems, including time-history elasto-plastic analysis of structures, soil-structure inter-elasto-plastic analysis of structures, soil-structure inter-action analysis etc. This extends to theoretical response spectrum for earthquakes of various magnitudes along particular faults. engineers have sufficient confidence in these spectrums to use them in their designs, a confidence which at present would be supported by few in this country. on the other hand, informal discussion with some designers indicated that they had little conviction of the value of sophisticated analysis procedures available but preferred to pay attention to detailing and capacity design requirements more in line with current proposals in draft New Zealand standards for seismic resistant design.

\section{SUMMARY AND CONCLUSIONS:}

(i) From the content of the course it is apparent that engineers in New Zealand are in general as advanced as their American counterparts in the understanding and use of modern seismic-resistant design and analysis techniques. In some areas of structural seismic engineering New Zealand developments are in the forefront of design philosophy, particularly in the fields of capacity design and reinforced concrete seismicresistant detailing.

(ii) A sound basis of engineering judgement and an appropriate literature search would be sufficient for anyone with broad seismic engineering experience to use modern developments covered in the course to solve an extensive range of both civil and structural seismic design problems.

(iii) There appeared to be a tendancy for some researchers to become involved in the solution of problems by sophisticated techniques more because of the elegance of the solution rather than whether the solution is of practical value and adds to the understanding of seismic engineering.

(iv) Attention to sound detailing of structural sub-assemblages and members gives better performance under earthquake attack than excessive attention to the sophistication of the analysis of response.

LIST OF REFERENCES:

1. Hoar, R.J. and Stokoe, K.H., II, (1978), "Generation and Measurement of Shear Waves in Situ", Dynamic Geotechnical Testing, ASTM STP 654, American Society for Testing and Materials, pp.3-29.

2. Hoar, R.J. and Stokoe, K.H. (1980b), "Investigation of Variables Affecting in Situ Seismic Wave Velocity Measurements," report submitted to the U.S. Army Engineering Waterways Experiment Station, CE, Vicksburg, MS .

3. Stokoe, K.H., II and Hoar, R.J. (1977), "Field Measurement of 
Shear Wave Velocity by Crosshole and Downhold Seismic Methods", Proceedings of the Conference on Dynamic Methods in Soil and Rock Mechanics, Vol. III, pp. 115-137.

4. Seed, H.B., and Lysmer, J., "The Seismic Soil-Structure Interaction Problem for Nuclear Facilities", a report prepared for the Lawrence Livermore Laboratory, April 1980.

5. Seed, H.B. (1979) "Considerations In The Earthquake Resistant Design of Earth and Rockfill Dams", Geotechnique 29, No. 3, pp. 215-263.

6. "Tentative Provisions for the Development of Seismic Regulations for Buildings", Applied Technology Council Publication ATC-3-06 (NSF Publication 78-8, NBS Special Publication 510), U.S. Govt. Printing Office, June 1978.

7. Chopra, A.K., "Earthquake Resistant Design of Concrete Gravity Dams", Journal of the Structural Division, ASCE Vol. 104, No. ST6, June 1978, pp. 953-971.

8. Chopra, A.K., Chakrabarti, P. and Gupta, S., "Earthquake Response of Concrete Gravity Dams Including Hydrodynamic and Foundation Interaction Effects," Report No. $\mathrm{UCB} / \mathrm{EERC} / 80 / 01$, University of California, Berkeley, Jan. 1980, $1987 \mathrm{pp}$.

9. Clough, R.W., Niwa, A. and Clough, D.P., "Experimental Seismic Study of Cylindrical Tanks", Journal of the Structural Division, ASCE, Vol. 105, No. ST12, Dec. 1979, pp. 2565-2590.

10. Penzien, J., and Tseng, S. "Numerical Methods in Offshore Engineering, Chapter 7, ThreeDimensional Dynamic Analysis of Fixed Offshore Platforms", Ed. by Zienkiewicz, John Wiley \& Son, 1978.

11. American Petroleum Institute, API Recommended Practice for Planning Desianing and Constructing Fixed Offshore Platforms, API Production Dept., loth Ed. March $1979,50 \mathrm{pp}$.

12. ACI. "Guide for the Design and Construction of Fixed Offshore Concrete Structures", ACI Report $357 \mathrm{R}-78,1978$.

13. Der Kiureghian, A., and Ang, A. H-S, "A Fault-Rupture Model for Seismic Risk Analysis", Bulletin of the Seismological Society of America, Vol. 67, No. 4, pp. 1173-1194, August 1977.

14. Popov, E.P., "Seismic Behaviour of Structural Subassemblages", Journal of the Structural Div, ASCE, Vol 106, No. ST7, July 1980. 